\title{
Malgorzata Czekaj, Doktryna wobec codzienności. Studium fenomenograficzne o wychowaniu religijnym w rodzinie, Kraków: NOMOS, 2015, s. 220.
}

DOI: http://dx.doi.org/10.12775/PCh.2015.039

Nakładem Zakładu Wydawniczego NOMOS ukazała się kolejna praca poświęcona współczesnym przemianom religijności Polaków. Jej autorka jest doktorem nauk społecznych Uniwersytetu Gdańskiego. Recenzowana książka stanowi efekt badań w ramach przygotowywania rozprawy doktorskiej. Składa się sześciu rozdziałów (trzy pierwsze o charakterze teoretycznym, pozostałe trzy odnoszą się do koncepcji badawczej i jej realizacji), zakończenia, aneksu zawierającego kwestionariusz wywiadu oraz bogatej bibliografii.

Za główny przedmiot badań autorka uznała wychowanie religijne w rodzinach, w których rodzice reprezentują orientację katolicką. Jednym z tropów dla własnych poszukiwań badawczych są między innymi wcześniejsze ustalenia lubelskiego socjologa moralności i religii Janusza Mariańskiego, który stoi na stanowisku, że atmosfera domu rodzinnego ma znaczący wpływ na kształtowanie się postaw młodzieży wobec religii. Wyniki jego badań wskazują, że ludzie młodzi o silnej postawie religijnej pochodzą z reguły z rodzin religijnych, podczas gdy niezdecydowani, obojętni na sprawy religijne i niewierzący - z rodzin niereligijnych. Nie jest tak jednak zawsze: młodzież o głębokiej religijności nie pochodzi wyłącznie z rodzin religijnych $\mathrm{i}$ - analogicznie - młodzież niereligijna nie zawsze pochodzi z rodzin niereligijnych ${ }^{1}$. Małgorzata Czekaj sformułowała w swoim procesie badawczym cztery główne cele poznawcze: 1) rekonstrukcja mapy znaczeń przypisywanych wychowaniu religijnemu; 2) poznanie oraz określenie modelu małżeństwa i rodziny w świetle obowiązujących dokumentów Kościoła rzymskokatolickiego oraz polskiego piśmiennictwa naukowego orientacji katolickiej; 3) poznanie modelu wychowania religijnego w świetle obowiązujących dokumentów Kościoła rzymskokatolickiego oraz polskiego piśmiennictwa naukowego orientacji katolickiej; 4) konfrontacja modelu wychowania religijnego, ujawnionego poprzez analizę obowiązujących dokumentów Kościoła rzymskokatolickiego (wersja doktrynalna), z rozumieniem wychowa-

${ }^{1}$ Janusz Mariański, Sekularyzacja i desekularyzacja w nowoczesnym świecie (Lublin: KUL, 2006), 81. 
nia religijnego przez rodziców reprezentujących orientację katolicką (wersja potoczna) $)^{2}$.

Należy zaznaczyć, że M. Czekaj dość odważnie zrezygnowała z terminu ,rodzina katolicka” (stosowanego w nauce Kościoła i literaturze przedmiotu) i zastappiła go konstrukcją językową: „,rodzina, w której rodzice reprezentują orientację katolicką”. Jak przekonuje autorka, ten zabieg językowy wiąże się z przyjęciem założenia, zgodnie z którym dzieci nie posiadają w pełni ukształtowanego samodzielnie własnego światopoglądu religijnego, lecz jedynie modelują zachowania rodziców³.

W Doktrynie wobec codzienności akcent położono na badanie aspektów świadomościowych, a religia definiowana jest z perspektywy funkcjonalistyczno-strukturalnej. W szczególności bliskie są autorce socjologiczne ujęcia religii (pojęcia uporządkowania doświadczeń Bergera oraz teorii systemu społecznego Luckmanna) $)^{4}$. Przytoczmy fragment wypowiedzi J. Mariańskiego, chętnie przywoływanego w Doktrynie wobec codzienności: „Główną funkcją jaką spełnia religia, jest konstruowanie sensu (Thomas Luckmann), przezwyciężanie przygodności (Niklas Luhmann), odkrywanie osobowej tożsamości (Hermann Lubbe), komunikowanie oparte na opozycji immanentne-transcendentne (Peter Beyer), zajmowanie się problemami ostatecznymi (Milton J. Yinger), konstruowanie świętego kosmosu (Peter L. Berger) i inne"s.

W rozdziale pierwszym pt. „Religia i religijność z perspektywy teoretycznej oraz empirycznej" wnikliwie przypomniano podstawowe funkcji religii oraz typologie religijności i jej parametry (wymiary empiryczne zjawiska, tj. aspekt znajomości prawd wiary, praktyk religijnych, aspekt integracyjny, poziomu moralnego, identyfikacji z Kościołem, świadomości i wiedzy religijnej). Ukazane zostały również współczesne przemiany religijności w rodzinie polskiej, przeobrażenia orientacji moralnej, zwrócono uwagę na pojawienie się nowych ruchów religijnych, fenomenu New Age czy takich zjawisk, jak religijność subiektywna i selektywność w przestrzeganiu praktyk religijnych. Za Ireną Borowiak M. Czekaj przyjmuje, że nowoczesną religijność charakteryzuje między innymi: pluralizm wyznaniowy, prywatyza-

2 Małgorzata Czekaj, Doktryna wobec codzienności. Studium fenomenograficzne o wychowaniu religijnym w rodzinie (Kraków: NOMOS, 2015), 11.

3 Tamże, 41.

${ }^{4}$ Czekaj odwołuje się przede wszystkim do prac: Peter Berger, Święty baldachim. Elementy socjologicznej teorii religii (Kraków: NOMOS, 2005) oraz Thomas Luckmann, Niewidzialna religia. Problem religii w nowoczesnym społeczeństwie (Kraków: NOMOS, 2011).

${ }^{5}$ Mariański, Sekularyzacja, 104. 
cja i deinstytucjonalizacja, indywidualizacja oraz globalizacja. Na podstawie analizy dostępnej literatury przedmiotu wnioskuje, że Polacy reprezentują zarówno cechy tradycyjnego, jak i nowoczesnego społeczeństwa.

Z kolei w rozdziale II: „Rodzina jako kategoria społeczno-pedagogiczna: definicje i typologie rodziny" zaprezentowano bogatą literaturę przede wszystkim z kręgu pedagogiki rodziny. Nakreślono obraz polskiej współczesnej rodziny - kierunki przemian (m.in. przejście od modelu tradycyjnego do nowoczesnego, zmianę roli kobiety w rodzinie, nowe alternatywne formy życia rodzinnego), jak również starano się wskazać na konsekwencje dla wychowania religijnego. Przede wszystkim jednak przybliżony został model małżeństwa i rodziny opracowany w świetle polskiego piśmiennictwa naukowego orientacji katolickiej. Przeprowadzone w tym zakresie rozpoznanie badawcze obejmuje analizę prac: zmarłego w lutym tego roku wybitnego filozofa i socjologa Leona Dyczewskiego oraz: Jerzego Laskowskiego, Mieczysława Gogacza, Jana Wyślickiego i Jacka Woronieckiego. Ponadto gruntowanie przestudiowano model małżeństwa i rodziny katolickiej w świetle obowiązujących dokumentów Kościoła rzymskokatolickiego. W dalszej kolejności analizie poddano modele wychowania religijnego $\mathrm{w}$ rodzinie $\mathrm{w}$ pracach badaczy orientacji katolickiej, w szczególności: Stefana Kunowskiego, Mariana Nowaka, Józefa Tischnera oraz Jerzego Bagrowicza, jak również model wychowania religijnego w rodzinie w świetle obowiązujących dokumentów Kościoła rzymskokatolickiego (temu poświęcono rozdział III).

Po lekturze rozdziału IV pt. „Ogólne założenia badań fenomenograficznych" należy podkreślić, iż autorka posiada staranne przygotowanie metodologiczne. Próba rekonstrukcji modelu wychowania religijnego postrzegana jest przez M. Czekaj w kategoriach weberowskigo typu idealnego, wyznaczającego określone zadania i cele aspirujące do empirycznej ważności ${ }^{6}$. Perspektywą interpretacyjną staje się podejście fenomenologiczne, a właściwie jego podtyp - fenomenograficzne Ferenca Martona. Młoda badaczka przeprowadziła dwadzieścia wywiadów z osobami w wieku od 40 do 59 lat. Badaniami objęte zostały małżeństwa sakramentalne Kościoła rzymskokatolickiego, które posiadają pełnoletnie potomstwo. Zdaniem autorki taka próba badawcza umożliwiła wyłączenie z zakresu badań okresu kryzysu tożsamości występującego podczas dorastania dzieci i zwrócenie uwagi na rezultaty osiagnięte przez te małżeństwa na etapie stabilizacji życiowej. W grupie badawczej znaleźli się rodzice należący do wspólnoty przykościel-

${ }^{6}$ Czekaj, Doktryna, 123.

7 Tamże, 12. 
nej Kościoła Domowego (10 wywiadów) oraz rodzice niezrzeszeni w żadnej organizacji przykościelnej (10 wywiadów). Różnice uzyskanych rezultatów są znamienne. Pierwsza grupa osób świadomie, regularnie oraz dobrowolnie angażuje się w życie Kościoła, stale poszerza swoją wiedzę z zakresu doktryny katolickiej, aby - w sposób najbardziej zbliżony do modelu obowiązującego w Kościele - wychowywać religijnie dzieci

Zgromadzony materiał empiryczny w rodziale V, zatytułowanym „Prezentacja wyników badań fenomenograficznych", ujawnił cztery sposoby pojmowania wychowania religijnego przez rodziców. Jest on niezwykle interesujący, dlatego też warto przytoczyć jego główne ramy:

1. Najczęściej wychowanie religijne postrzegane jest przez badanych jako świadectwo wiary. Respondentki i respondenci za najwłaściwszy instrument przekazu myśli chrześcijańskiej uznają oddziaływanie rodziców charakteryzujące się autentycznością reprezentowanych przez nich postaw.

2. Przygotowanie do życia to kolejne znaczenie wychowania religijnego. W tej perspektywie badani odnoszą się do sfery życia doczesnego, a więc do społeczeństwa i kultury.

3. Następnym ujawnionym znaczeniem wychowania religijnego jest proces, który zdaniem rodziców nigdy się nie kończy. Zgodnie z tym rozumieniem rodzice powinni przez całe życie doradzać swoim dzieciom w kwestiach wiary (nawet tym pełnoletnim - jednak tylko wówczas, gdy same dzieci wyrażają na to zgodę).

4. Prawo dane i zadane to czwarte ujawnione znaczenie wychowania religijnego. Jednak tego typu interpretacja pojawia się wyłącznie wśród wypowiedzi badanych należących do wspólnoty Kościoła Domowego. Wskazani rodzice pojmują wychowanie religijne zarówno jako dar od Boga, jak i konkretne zadania, które mają obowiązek realizować. W tak określonej definicji widoczna jest próba przekroczenia wymiaru rzeczywistości doczesnej, co nie ujawnia się w opiniach badanych rodziców spoza wspólnoty9.

Atutem pracy jest także stworzenie modelu wychowania religijnego, zawierającego zestaw wskazówek, jak - zdaniem rodziców - powinno wyglądać wychowanie religijne w rodzinie katolickiej. Wiele do rozważań nad religijnością współczesnych polskich rodzin może wnieść także rozdział VI:

\footnotetext{
8 Tamże, 191.

9 Tamże, 189-190.
} 
„Świadomościowy wymiar wychowania religijnego”, w którym autorka zestawia zakresy rozumienia wychowania religijnego zbieżne z modelem postulowanym w świetle obowiązujących dokumentów Kościoła rzymskokatolickiego oraz zakresy rozumienia wychowania religijnego rozbieżne z modelem postulowanym (te ujawniają narracje rodziców, którzy nie należą do wspólnoty formacyjnej Kościoła Domowego). Wypowiedzi tej grupy badanych pokazują, że traktują oni wychowanie religijne jako ,proces nieintencjonalny, a więc niezamierzony, bezrefleksyjny oraz spontaniczny [...]. Działania wychowawcze podejmowane przez tę grupę badanych realizowane są często po to, aby spełnić codzienne, lokalne i społeczne oczekiwania, których podłożem jest wyłącznie tradycja oraz emocje. Działania takie nie zmierzają więc do rozwijania pogłębionego stopnia relacji człowieka z Bogiem" ". Różnice ujawniają się między innymi na płaszczyźnie słabszego teoretycznego przygotowania rodziców oraz w postaci selektywnego traktowania założeń religijnych (np. w kwestiach akceptacji antykoncepcji, współżycia przed ślubem czy dopuszczalności rozwodów).

Zebrany materiał empiryczny jest niezwykle bogaty. Czasami budzi niedosyt liczba zaprezentowanych fragmentów wypowiedzi respondentów, autorka zdecydowała się bowiem na wprowadzenie przede wszystkim własnej narracji po przeanalizowaniu wypowiedzi. W książce nie odnajdziemy zbyt wielu informacji biograficznych o badanych rodzinach, przydałoby się również przeprowadzenie rozmów z dorosłymi dziećmi badanych. Wnioski $z$ badań to jednakże wiedza skondensowana, usystematyzowana i niezwykle wartościowa.

Małgorzata Czekaj ostatecznie dochodzi do sformułowania konkluzji, iż koncepcje postulowane w świetle nauki Kościoła rzymskokatolickiego nie są wystarczająco (z punktu widzenia dobra tego Kościoła) rozpowszechnione w ramach szeroko pojętej edukacji religijnej ${ }^{11}$. Jej zdaniem: ,,rezultaty dociekań teoretycznych (poznanie modelu małżeństwa i rodziny oraz modelu wychowania religijnego w rodzinie w świetle obowiązujących dokumentów Kościoła rzymskokatolickiego oraz polskiego piśmiennictwa naukowego orientacji katolickiej), a także wnioski wywiedzione w obszarze badań empirycznych (studium fenomenograficzne), mogą wnieść wkład w teorię rodziny, przy możliwości jednoczesnego ich wykorzystania w celach praktycznych, szczególnie w ramach pedagogiki rodziny oraz pedagogiki religii”'12.

\footnotetext{
10 Tamże, 186-187.

11 Tamże, 193.

12 Tamże, 16.
} 
Po lekturze tegoż jakże interesującego studium fenomenograficznego należy w pełni zgodzić się z jego autorką.

Joanna Cukras-Stelagowska*

\section{Janusz Mariański, Marek Marczewski (red.), Pedagogika rodziny. Podejście interdyscyplinarne, Gdańsk: Wyższa Szkoła Społeczno-Ekonomiczna, 2015, s. 379.}

DOI: http://dx.doi.org/10.12775/PCh.2015.040

Ważnym aspektem refleksji podejmowanej w pedagogice jako dyscyplinie naukowej jest jej interdyscyplinarność. Pojęcie interdyscyplinarności zaznacza fakt korzystania $\mathrm{w}$ jej obrębie $\mathrm{z}$ dorobku innych nauk. Trudno zatem wyobrazić sobie badania nad wychowaniem z pominięciem nauk społecznych, humanistycznych, jak również przyrodniczych. Tak rozumiane badania z całą pewnością wzbogacają rozumienie badanych zjawisk, pozwalając tym samym na bardziej zróżnicowane widzenie samej pedagogiki.

Punktem wyjścia dla analiz omawianej publikacji zbiorowej niech będzie jej tytuł. Wskazuje on na zaakcentowanie związku subdyscypliny, jaką jest pedagogika rodziny, z jej podejściem interdyscyplinarnym. Publikacja pod redakcją Janusza Mariańskiego i Marka Marczewskiego Pedagogika rodziny. Podejście interdyscyplinarne wskazuje zatem na obecność dyscyplin pomocniczych w pedagogice rodziny. Przedmiotem dociekań naukowych tej subdyscypliny jest teoretyczna refleksja oraz badania nad rodziną z pozycji pedagogicznej, czyli chodzi tutaj o wychowanie rodzinne ujmowane w szerokim znaczeniu, z uwzględnieniem jej różnorodnych aspektów.

Opracowanie składa się z ośmiu tekstów, ukazujących różnorodne konteksty dyscyplinarne. Autorką pierwszego rozdziału jest dr hab. Danuta Opozda. Opracowanie pod tytułem Subdyscyplinarny charakter pedagogiki rodziny służy wyjaśnieniu kontekstu metodologiczno-postulatywnego. Wykazano, iż rozwój wiedzy pedagogicznej winien przyjmować teoretycznopraktyczny charakter, przez co należy rozumieć konstruowanie wiedzy o rodzinie w odniesieniu do edukacji, co w końcowym etapie ma prowadzić do ulepszenia praktyki edukacyjnej.

* Dr Joanna Cukras-Stelagowska jest adiunktem w Katedrze Teorii Wychowania na Wydziale Nauk Pedagogicznych Uniwersytetu Mikołaja Kopernika w Toruniu. Adres: Wydział Nauk Pedagogicznych UMK, ul. Lwowska 1, 87-100 Toruń; e-mail: joanstel@umk.pl. 